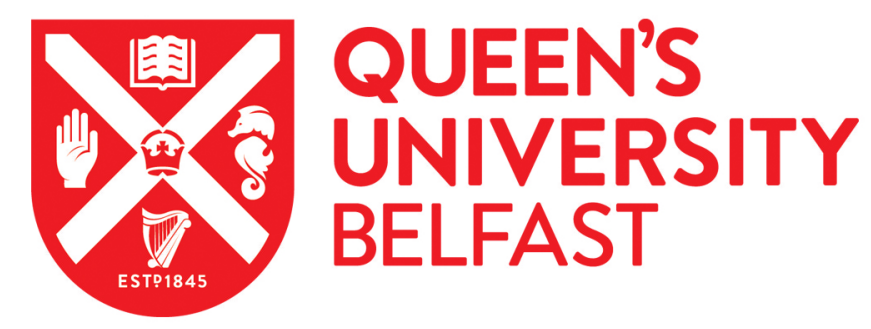

\title{
Doing a Case Study on Health Care Quality Improvement at a Large Public Teaching Hospital: A Non-Clinician's Account
}

Melo, S. (2019). Doing a Case Study on Health Care Quality Improvement at a Large Public Teaching Hospital: A Non-Clinician's Account. SAGE Research Methods: Cases, SAGE Research Methods Cases Part 2. https://doi.org/10.4135/9781526477996

\section{Published in:}

SAGE Research Methods: Cases

\section{Document Version:}

Peer reviewed version

Queen's University Belfast - Research Portal:

Link to publication record in Queen's University Belfast Research Portal

\section{General rights}

Copyright for the publications made accessible via the Queen's University Belfast Research Portal is retained by the author(s) and / or other copyright owners and it is a condition of accessing these publications that users recognise and abide by the legal requirements associated with these rights.

Take down policy

The Research Portal is Queen's institutional repository that provides access to Queen's research output. Every effort has been made to ensure that content in the Research Portal does not infringe any person's rights, or applicable UK laws. If you discover content in the Research Portal that you believe breaches copyright or violates any law, please contact openaccess@qub.ac.uk. 


\section{SAGE Research Methods Cases Business \& Management Submission for Consideration}

\section{Case Title}

Doing a case study on healthcare quality improvement at a large public teaching hospital: a non-clinician's account

\section{Author Name(s)}

Sara Melo

\section{Author Affiliation \& Country of Affiliation}

Queen's Management School, Queen’s University Belfast, UK

\section{Lead Author Email Address}

Email: s.melo@qub.ac.uk

Discipline: D5 [please do not alter]

Sub-discipline within Business \& Management

General Business and Management [SD-BM-1]

Academic Level of intended readership

Postgraduate

\section{Contributor Biographies}

Sara Melo, PhD is a Lecturer in Management at Queen's Management School, Queen's University Belfast. Previously she worked as a Research Fellow and Project Manager at Trinity College Dublin and as a Teaching Fellow in Public Sector Management at The York Management School, University of York, where she received her PhD in Management. Her main research interests include the design and implementation of innovations within 
organisations, translation of research evidence into practice, quality improvement, and organisational learning, particularly in the healthcare sector.

\section{Published Articles}

Melo, S. (2018). The role of place on healthcare quality improvement: A qualitative case study of a teaching hospital. Social Science \& Medicine. 202, 136-142.

Melo, S. (2016). The impact of accreditation on healthcare quality improvement: A qualitative case study. Journal of Health Organization and Management. 30, 1242-1258.

Melo, S. \& Beck, M. (2015). Intra and inter-organisational learning networks and the implementation of quality improvement initiatives - the case of a Portuguese teaching hospital. Human Resource Development Quarterly. 26(2), pp. 155-183.

\footnotetext{
Abstract

This research methods case is based on research undertaken as part of a $\mathrm{PhD}$ in Management. The $\mathrm{PhD}$ focused on exploring the processes through which patient safety is improved by exploring how a bottom-up falls prevention initiative started and developed in an acute hospital setting. This research contrasted with most of the existing patient safety research at the time, which focused on how top-down patient safety management initiatives could ensure patient safety. Given the exploratory nature of the $\mathrm{PhD}$ research, the bulk of this research was based on an empirical case study conducted in an acute teaching hospital in Portugal, which drew on an ethnographic approach. Fieldwork followed a staged-approach. An initial visit to the hospital took place in August 2008 which informed the formal context interviews which were conducted in June 2009. Main data collection took place between December 2009 and February 2010. In total, 46 in-depth interviews were conducted with 49 clinical and nonclinical staff members. The adoption of a staged-approach helped to shape the research according to the context of the hospital and in so doing allowed a more in-depth case study of the hospital.
} 


\section{Learning Outcomes}

By the end of this case, students should be able to:

1. understand how the research objectives impact on the research design and evaluate if a case study is the most suitable design for a specific research project

2. understand how the design of a case study impacts on data collection methods and on the quality of data collected

3. discuss the influence of the case study setting and the researcher on data collection strategies and the quality of data collected

4. recognise that the same data set can be analysed using different methods in response to different objectives

\section{Case Study}

\section{Project Overview and Context}

I always had a keen interest on healthcare management. As part of my undergraduate degree in management, I did a three-month internship at a district public hospital in Portugal where, after finishing my undergraduate, I worked for near one year.

Similarly, when embarking on doing a PhD in Management, I wanted to conduct research on healthcare management. I was particularly interested on performance management. Given that performance is a very broad topic, after reading literature I became interested on quality management. Yet, healthcare quality management is still a multi-faceted topic and thus I decided to focus on patient safety. Alongside other dimensions such as effectiveness; efficiency; access to care; equity; appropriateness; timeliness; acceptability; responsiveness; satisfaction; health improvement and continuity (Legido-Quigley, McKee, Nolte, \& Glinos, 2008), at the time I started my PhD (March 2007), patient safety was considered as one of the key aspects of the quality of care provided to patients by healthcare institutions. 
Particularly in developed countries such as the US, the UK, Canada, and Australia, patient safety had attracted significant attention not only from researchers but also from politicians, governments and the general public and since the late 1990s, patient safety had come to be considered as one of the key dimensions of the quality of care provided by healthcare institutions. As a result, the topic of patient safety was, and still is, a critical topic. Additionally, at the time I embarked on doing a $\mathrm{PhD}$, although patient safety was one of the most topical themes on healthcare management, it was considered a relatively new discipline. The mainstream literature on patient safety had focused on the causes and consequences of patient safety incidents and the proposition of primarily top-down, managerialist interventions (e.g. standard procedures for hand-washing). The proponents of these approaches have been described as empiricists and organisational rationalists (Joyce, Boaden, \& Esmail, 2005). A third and less prominent approach, which has been labelled as 'professional culture promoters' (Joyce et al., 2005), focused on the role of professional socialisation and training as well as the way professionals perceive and deal with risk. Overall, due to the empiricist and managerialist orientation of mainstream patient safety research, comparatively little was known about the human and non-human components of patient safety improvements as real world processes.

In order to contribute to address this gap, the main objective of this study was to conduct an in-depth analysis of how patient safety can be improved in practice. The main aim of the thesis was not to find, provide, or prescribe solutions for patient safety. Rather, the aim of this research was to understand and to analyze the dynamics involved in the creation and development of patient safety initiatives and to explore the factors that contribute for the success or otherwise of these initiatives.

As described in the next sections, although the research objectives influenced the choice of the research design, the design adopted also shaped the research objectives.

\section{Research Design}

\section{Rational for choosing a single case study}

In order to attain the research objectives, this research adopted a case study design which was conducted in a staged way and drew heavily on an ethnographic approach. A case study was chosen as this study design is useful in providing a rich description of the complexities of a situation and thus contributing for the understanding of a larger phenomenon (Rossman $\&$ Rallis, 2003). This study followed Rossman \& Rallis' (2003) perspective that an “ethnographer seeks to understand insiders' views of their lives - the emic view -and render 
an account of that cultural worldview." (p. 95). As a result, data collection was not informed by pre-defined hypothesis or based on specific theories, as doing so can actually hinder the researcher's ability to become conscious of the theories that explain the object of study (Denzin, 2008).

Given the fact that I did not have an in-depth knowledge of the hospital, I decided to conduct research following a staged approach. I started by doing a pilot visit to the hospital in August 2008 to explore the potential of the hospital as a case study setting and data were collected in two stages. The first stage of eight interviews involving nine interviewees took place in June 2009. The aim of these 'context' interviews was to obtain a broad picture of the factors underlying the rise of quality and patient safety in the hospital's agenda, the existing clinical governance systems, and the quality and patient safety initiatives that have been adopted by the hospital. Based on this information, the Falls Prevention Group and a project aimed at improving the hospital's accessibility were chosen as the units of analysis of subsequent 'main' data collection. The second stage of 38 interviews involving 41 interviewees were conducted between December 2009 and January 2010. These interviews focused on exploring the organisational dynamics associated with the start and development of these two projects. Due to the small size of the accessibility project and for the purpose of simplicity, this case study only focuses on the falls prevention project.

Finally, the choice of a single case study was motivated by time constraints which would only allow conducting one in-depth case study.

\section{Choice of the hospital case study, pilot visit and context interviews}

The hospital chosen for this case study is an acute teaching hospital which employed more than 3,200 staff and is part of the Portuguese National Health Service, located in the north of Portugal. This choice was based on several grounds:

1. from informal personal contacts with professionals working in Portuguese hospitals, I understood that this hospital was one of the pioneer hospitals in Portugal to implement quality and patient safety improvement initiatives,

2. during the pilot visit to the hospital in August 2008, I was able to confirm the high degree of development of quality and patient safety improvement projects inside the hospital, and

3. hospital staff showed interest in collaborating with the research.

In September 2008 I sent a formal request to obtain the permission to conduct a case study in the hospital. After obtaining ethics approval from both the University and the hospital, eight 
formal interviews with nine interviewees were conducted in June 2009. The interviewees hailed from an array of departments including catering services; premises and equipments; quality, risk, hygiene, health and safety management (henceforth quality management department); sterilisation; social services; customer care department; and human resource department. In terms of their professional qualification the interviewees included one doctor, two nurses, one laboratory technician, two managers, two social workers, and one engineer. As mentioned above, based on data gathered during the pilot visit and the context interviews, I decided to focus the research on the Falls Prevention Group.

The Falls Prevention Group had been created in 2006 as a bottom-up initiative, rather than in response to guidelines from the Portuguese Ministry of Health or the quality accreditation process. Specifically, the group had been formed as a result of the awareness that falls were the most reported clinical incident and a desire of a group of professionals linked to the quality management department to reduce the severity of falls and repeat falls. Initially, the Falls Prevention Group was formed by six members, three members of the quality management department, a doctor, an engineer, and a lab technician; and three nurses belonging to three of the departments with the highest number of reported falls. The basic structure of the Falls Prevention Group remained the same until 2009. In 2009, the Falls Prevention Group was restructured and started to include only nurses.

\section{The focus on the Falls Prevention Group as the unit of analysis}

The focus on the Falls Prevention Group was motivated by several reasons. First and foremost, alongside its bottom-up nature, the Falls Prevention Group was chosen because of the importance the hospital attributed to this project. Context interviews suggested that the Falls Prevention Group had been one of the biggest patient safety projects adopted by the hospital and that during those three years, from 2006 to 2009, the Falls Prevention Group had implemented several concrete projects, which had benefited the hospital as a whole. Second, given the aim to study how the innovations for improving patient safety introduced in the hospital spread beyond professional boundaries, it was important to choose a topic that all professionals working in the hospital would understand. Third, given my non-clinical background and time constraints, the Falls Prevention Group seemed an appropriate subject of study. Specifically, the study of this project would not require me to obtain advanced clinical knowledge in order to be able to collect and analyse data. Finally, the Falls Prevention Group had been created three years before (2006). Given that the project was relatively recent, this increased the possibility of interviewing professionals that were directly 
involved in the beginning of the project, still working in the hospital. Moreover, it was expected that interviewees would be able to recall past events related with the Falls Prevention Group. Thus, choosing a relatively recent initiative was seen as a means of ensuring a reasonable level of trustworthiness of the interview data collected.

\section{Main data collection methods}

Data was collected mainly through individual, face-to-face, in-depth semi-structured interviews. Interviews are considered to be one of the most important sources of evidence of qualitative research (Denzin \& Lincoln, 2008) and of case studies (Yin, 2009). Indeed, as described above, context interviews informed me about the Falls Prevention Group which then became the main unit of analysis of the following interviews (see also section "Method in Action" for a description of how evidence collected during context interviews influenced the conceptual framing of the research).

Other sources of secondary data were used to complement data collected during the interviews. These included the website, statistics, presentations, and annual reports from the case study hospital; information about the hospital published in magazines; and documents from the Portuguese Ministry of Health. These sources were also used in the triangulation of data from different sources in order to assess the consistency of findings drawn from different data sources (Flick, 2007).

\section{Research Practicalities}

When conducting the case study, a number of practicalities were taken into consideration, as described in the table below:

\begin{tabular}{|l|l|}
\hline Issue & Practicalities \\
& Data was collected in three stages (pilot visit in August \\
& 2008, context interviews in June 2009 and main \\
interviews from December 2009 - February 2010). & The significant duration of the data collection (more \\
& than three months in total) and the face-to-face \\
character of interviews, required me to live near the \\
case study during most of data collection. Thus, when \\
choosing the case study, I also took into consideration \\
its location not only in terms of physical access (e.g. \\
easiness of travel, no need to obtain visas, etc.) but also \\
associated costs of living near the case study setting \\
during data collection. During data collection I stayed \\
at relative's house.
\end{tabular}




\begin{tabular}{|c|c|}
\hline Gatekeeper & $\begin{array}{l}\text { Having a helpful gatekeeper was critically important. } \\
\text { Previous to the research, I knew a member of staff } \\
\text { working at the case study hospital. When I was } \\
\text { considering the hospital as a potential case study, I } \\
\text { contacted them and asked their opinion about who } \\
\text { would be the best person to contact inside the hospital. } \\
\text { This person then became my gatekeeper inside of the } \\
\text { hospital and was key in helping me to know more about } \\
\text { the hospital as well as putting me in contact with } \\
\text { potential interviewees. }\end{array}$ \\
\hline Sample of participants & $\begin{array}{l}\text { As an outsider to the case study hospital, it would be } \\
\text { very difficult for me to identify the most relevant } \\
\text { interviewees working inside the hospital. Thus, } \\
\text { potential interviewees were chosen using a snowball } \\
\text { approach in that interviewees suggested other potential } \\
\text { interviewees (Black, 2002). } \\
\text { However, given that I was interested in obtaining } \\
\text { different points of view, I asked interviewees to } \\
\text { purposely indicate professionals working across a } \\
\text { variety of departments. This allowed obtaining a better } \\
\text { picture of the case study as a whole. }\end{array}$ \\
\hline Time and place of interviews & $\begin{array}{l}\text { All interviews took place in the hospital at a time and } \\
\text { place suggested by interviewees. In practice this meant } \\
\text { that some interviews took place quite early in the } \\
\text { morning and others quite late at night. } \\
\text { This flexibility was key to conduct high quality } \\
\text { interviews as interviewees were asked to select a time } \\
\text { that would suit them best and this helped to ensure that } \\
\text { they had appropriate time and attention to dedicate to } \\
\text { the interview. } \\
\text { The fact that interviews ended up taking place in } \\
\text { interviewees' offices or in meeting } \\
\text { rooms/administrative areas near their workplace, meant } \\
\text { that it was not only a familiar place for interviewees but } \\
\text { also the most convenient place for them. Additionally, } \\
\text { it facilitated interviewees showing me some of the } \\
\text { things they mentioned during interviews (e.g. features } \\
\text { of the built environment, objects used in falls } \\
\text { prevention), etc. }\end{array}$ \\
\hline Access to secondary data & $\begin{array}{l}\text { The fact that interviews took place inside the hospital } \\
\text { also facilitated interviewees to show me and give me } \\
\text { secondary data that they were mentioning during } \\
\text { interviews (e.g. fall statistics, hospital photos before } \\
\text { and after refurbishments, etc.) }\end{array}$ \\
\hline Ethical considerations & $\begin{array}{l}\text { Obtaining ethics approval to conduct research in } \\
\text { hospitals is normally a very lengthy process that can } \\
\text { take several months and in some contexts more than } \\
\text { one year. In addition to the challenges associated with } \\
\text { this timeframe, there are differences in the ethics } \\
\text { process across national and regional contexts and }\end{array}$ \\
\hline
\end{tabular}




\begin{tabular}{|c|c|}
\hline & $\begin{array}{l}\text { hospitals. } \\
\text { The fact that I contacted the case study quite early } \\
\text { helped to ensure that I would have enough time to } \\
\text { collect data in the case study or to search for another } \\
\text { case study, if this was needed. } \\
\text { The help of the gatekeeper suggested by my contact } \\
\text { was crucial in the ethics approval process as they } \\
\text { helped me to understand the ethics approval process of } \\
\text { the hospital. } \\
\text { Before embarking on data collection, ethics approval } \\
\text { was obtained from both the university and the case } \\
\text { study hospital. These procedures were aimed at } \\
\text { assuring that this study met the expected ethical } \\
\text { principles such as anonymity, confidentially, and } \\
\text { informed consent pointed out by authors such as } \\
\text { Rossman and Rallis (2003). Before each interview } \\
\text { started, I verbally explained the aims and objectives of } \\
\text { the study and written informed consent was obtained } \\
\text { from the interviewee(s). In addition, an information } \\
\text { sheet of the study, written in Portuguese, including my } \\
\text { contact details, was given to interviewees. } \\
\text { Data was stored in laptops and computers protected by } \\
\text { password, and was not shared with anyone else. In } \\
\text { order to guarantee confidentiality and anonymity, I } \\
\text { personally transcribed all interviews. I anonymized } \\
\text { interview transcripts by allocating a code to each } \\
\text { interviewee. Details regarding interviewees were kept } \\
\text { on a different file. }\end{array}$ \\
\hline $\begin{array}{l}\text { The role of language and broader } \\
\text { cultural context on data collection } \\
\text { and data analysis }\end{array}$ & $\begin{array}{l}\text { Given the in-depth nature of the research, being } \\
\text { familiar with the structure and functioning of the } \\
\text { Portuguese National Health Service; the country's } \\
\text { cultural context and being a native speaker of the native } \\
\text { language of all interviewees greatly helped not only in } \\
\text { establishing rapport with interviewees but also in fully } \\
\text { understanding them during interviews. } \\
\text { This knowledge of the context subsequently helped me } \\
\text { on data analysis as I was able to understand the nuances } \\
\text { of the data, including some regional ways of saying } \\
\text { things. Interviews were conducted and transcribed in } \\
\text { Portuguese. Only the quotations that were used in the } \\
\text { thesis and publications were translated into English. }\end{array}$ \\
\hline
\end{tabular}

\section{Method in Action}

Conducting an in-depth case study following an ethnographic approach had a series of influences on the research. In order to describe the case study method in action, this section reflects on its impact on:

1. interviewees and duration of interviews, 
2. framing of research and design of the interview guide,

3. data analysis and reporting of the findings, and

4. what went well, what didn't go to plan, and what were the actions taken to respond to the challenges.

\section{Interviewees and duration of interviews}

As mentioned above, in both stages of interviews (contextual and main interviews) interviewees were purposefully chosen from a variety of departments and occupational groups. As mentioned above, context interviews took place in June 2009.

The main data collection stage took place from December 2009 to February 2010. Thirtyeight interviews involving 41 interviewees were conducted with doctors (7), nurses (24), nurse aides (4), administrative staff (2), health, hygiene and safety at work technicians (2), and engineers (2), working in several clinical and non-clinical services including internal medicine, cardiology, accidents and emergency, general surgery, other clinical departments, premises and equipments, and quality management department.

In terms of duration, context interviews lasted from 36 minutes to 120 minutes and the average duration was of 67 minutes and main interviews lasted from 12 to 114 minutes and the average duration was 39 minutes. The shorter duration of main interviews was due to the fact that whereas context interviews were conducted with staff that had an in-depth knowledge of the hospital's quality and patient safety projects, main interviews also included some occupational groups (e.g. administrative staff, nurse aides) that had a more peripheral role and/or lack of in-depth knowledge, hence resulting in shorter interviews.

Overall, 46 interviews, involving 49 interviewees were conducted and the average duration was 43 minutes. In total, four interviews (one context interview and three main interviews) were joint interviews involving two professionals. This happened due to pragmatic reasons such as office sharing and interviewees' time constraints. In all four cases, I felt that conducting joint interviews did not negatively impact on interviewees' participation during the interview.

\section{Framing of research and design of the interview guide}

The use of a single qualitative case study conducted following a staged-approach not only directly influenced data collection but also shaped the conceptual framing of the research and in so doing influenced the entire research process, including data collection. 
In this research, the relevance of the literature on communities of practice and organisational learning emerged from the pilot visit and context interviews. Indeed, both empiricist and organisational rationalist approaches to patient safety had been criticised for failing to adequately account for organisational dynamics (see for example Currie, Humpreys, Waring, \& Rowley, 2009; McDonald, Waring, \& Harrison, 2006; Waring, Harrison, \& McDonald, 2007) and, in particular, the ability of those involved in health care provision to learn or unlearn skills and adapt to changing environments. Also, traditional research on patient safety places a strong emphasis on top-down and managerialist approaches and has often been based on the assumption that 'safety' learning is primarily formal and context-independent. Evidence from the pilot visit and context interviews suggested that bottom-up initiatives rooted in communities of practice (Lave \& Wenger, 1991) and a combination of formal and informal learning can make a major contribution to patient safety improvements. This is in line with literature on workplace learning that argues that workplace learning is primarily informal (Malcolm, Hodkinson, \& Colley, 2003; Slotte, Tynjälä, \& Hytönen, 2004) and that, despite having different features, formal and informal learning can be combined (Malcolm et al., 2003; Tynjälä \& Häkkinen, 2005). Initial contacts with the hospital also evidenced that the context of learning is important in the learning process itself, which confirms some of the assumptions of the organisational learning literature (Lave \& Wenger, 1991).

These findings from the pilot visit and context interviews helped to place a stronger focus on the importance of social networks and learning during the main data collection, therefore framing the interview guide that was used in the main interviews.

Additionally, during the pilot visit and the contextual interviews it was very evident that alongside hospital's staff social networks and learning, patient safety initiatives and outcomes were also significantly influenced by other factors including the hospital's board, the country's Ministry of Health, aspects related to the patient, patient's family and patient's treatment (e.g. medication) as well as non-human elements such as:

- physical infrastructures such as buildings or parts of it (e.g. floor coverings),

- equipments (e.g. side rails, walking aids),

- furniture (e.g. beds, chairs, and bedside tables),

- materials (e.g. slippers, call bells)

- information systems (e.g. computers, software),

- hospital processes (e.g. procedures in case of a fall, procedures to prevent a fall),

- hospital policies (e.g. human resource allocation), and 
- financial resources

This led to the inclusion of questions related with these factors in the interview guide used in the main data collection interviews.

Although different fields studying healthcare (e.g. nursing, falls prevention, patient safety, medical sociology, science and technology studies) have identified many of the elements pointed out by interviewees as important, the fact that interviewees mentioned them greatly facilitated me in drafting the interview guide for the main interviews as they directed me towards what was most relevant in the case study hospital. Without the pilot visit and context interviews, I would need to read a lot more literature in order to become familiar with the clinical and non-clinical context of a large teaching hospital and even doing so, this knowledge obtained would inevitably differ from the specificities of the case study hospital.

\section{Data analysis and the reporting of the findings}

There are many ways of analysing qualitative data. When considering the most appropriate way of analysing data, there are two main elements that need to be considered:

1 - the data itself

2 - the objectives of the research

In practice, the same dataset can be analysed in different ways, if it is being used to answer different research objectives. This is what happened with the interview data that was collected in this case study. Data analysis for the article Melo (2018) was conducted following Braun \& Clarke's (2006) guidelines on thematic analysis. Coding focused on interviewees' views of their experiences and was performed manually by reading the interview transcripts, highlighting and writing notes on key sections. Initial codes were often defined using interviewees' own words. Relevant coded extracts were copied into a separated Microsoft Word file and further analysed in a more detailed way. The initial codes were reviewed and grouped into sub-themes and themes using visual thematic maps (Braun \& Clarke's, 2006).

Data analysis for the article Melo (2016) followed the framework thematic analysis (Spencer, Ritchie, Ormston, O’ Connor, \& Barnard, 2014). As Spencer et al. (2014) describe, this method of analysis involves:

1 - Familiarisation with the data

2 - Constructing the initial thematic framework (i.e. identify initial themes or concepts) 
3 - Indexing and sorting the data by applying the framework to the data

4 - Reviewing data extracts

5 - Summarising or synthesising the data

The fact that Melo's $(2018,2016)$ articles had very specific objectives fostered the use of more systematic ways of coding as well as coding at a more minutious level than the one adopted in the PhD thesis (Melo, 2012) and on the article Melo \& Beck (2015). In both, the $\mathrm{PhD}$ thesis and Melo \& Beck's (2015) article, data analysis followed the method proposed by Scapens (2004) where themes and patterns were identified by reading the interview transcripts several times and highlighting the key ideas.

As pointed out by Earthy and Cronin (2008), research methods that focus on "accessing an “"emic' perspective (i.e. an insider's understanding of a social situation or experience) will allow and often encourage the telling of stories" (p. 429). As a result, interviews normally comprised of several long narratives, sometimes of several pages long. The richness of the interviews, alongside the exploratory nature of the research aims of the $\mathrm{PhD}$ thesis and Melo \& Beck's (2015) article, favoured the use of a loose inductive design of data analysis. Loose inductively designs are particularly recommended for complex, single case studies, conducted in unfamiliar settings and when the main objective of the case study is descriptive or exploratory (Huberman \& Miles, 2008). In this way, data was analysed following what Lieblich, Tuval-Mashiach \& Zilber's (1998) identify as holistic-content type of narrative analysis. This mode of narrative analysis considers the entire story and focuses on its content (Lieblich et al., 1998). Analysis aimed at exploring the development of quality and patient safety initiatives, their impact on interviewees' day-to-day work and the meanings attributed to these changes and focused on the "surface content (what happened?, who was present?, how did different parties react?) and the underlying or latent content (what were the motives or intentions of participants?, what might particular items symbolise for the narrator or others?, what is the meaning and importance of this story for the narrator?)" (Earthy and Cronin, 2008, p. 433).

\section{What went well? What didn't go to plan, and what were the actions taken to respond to the challenges}

Amongst the several factors that contributed to the success of this research, the high degree of development of the quality and patient safety improvement initiatives of the case study hospital and the collaboration of hospital staff towards the research were crucial. Taken 
together, these fostered in-depth semi-structured interviews where interviewees provided rich accounts of the processes of development of falls prevention initiatives.

Given that the research started with the open aim of exploring where does patient safety initiatives come from, how they evolve and how they can be sustained, there was not a structured plan. Instead, the plan was to get insights from hospital staff from different clinical and non-clinical communities working in different departments in order to obtain a broad view of the topic. This quite unstructured approach is typical of interpretivism, which informed this research.

Looking back, although research took place in a quite smooth way, several challenges, which are typical of conducting case studies, could have taken place. These are presented in the table below, together with a reflection of actions that were adopted in order to minimize their possibility of occurrence:

\begin{tabular}{|c|c|}
\hline Potential issue & Actions adopted to minimize the issue \\
\hline $\begin{array}{l}\text { Inability of gaining } \\
\text { access to the case } \\
\text { study or not being } \\
\text { able to gain timely } \\
\text { access }\end{array}$ & $\begin{array}{l}\text { When doing a case study, one of the key challenges is not being } \\
\text { able to gain access to a relevant case study. In this research, } \\
\text { several actions were taken to minimize this risk: } \\
\text { - Conducting research on a familiar sector - as mentioned above, } \\
\text { the fact that I had worked in a public hospital in Portugal not } \\
\text { only gave me some valuable contacts in public hospitals in the } \\
\text { country but also allowed me to understand the structure and } \\
\text { entities that are part of the Portuguese National Health Service. } \\
\text { - Contacting the potential case study early - after some initial } \\
\text { months reading literature for my PhD, I started asking advice } \\
\text { about pioneer hospitals in Portugal in the area of quality and } \\
\text { patient safety and contacted the hospital. }\end{array}$ \\
\hline $\begin{array}{l}\text { Not being able to } \\
\text { interview enough } \\
\text { people with } \\
\text { knowledge on the } \\
\text { topic } \\
\text { - Interviewees not } \\
\text { being able to recall } \\
\text { past events }\end{array}$ & $\begin{array}{l}\text { In order to avoid these challenges, the case study focused on } \\
\text { the Falls Prevention Group which had started three years } \\
\text { before data collection. This increased the likelihood of being } \\
\text { able to interview staff that had been directly involved in the } \\
\text { process. } \\
\text { - Also, staff turnover in Portuguese public hospitals is relatively } \\
\text { low, thus making it easier to interview staff that were involved } \\
\text { in past projects. }\end{array}$ \\
\hline $\begin{array}{l}\text { Interviewees not } \\
\text { providing enough } \\
\text { detail during } \\
\text { interviews }\end{array}$ & $\begin{array}{l}\text { This is also a potential key challenge in qualitative case studies. } \\
\text { One of the key strategies to avoid this is to ensure that the } \\
\text { interviewer has appropriate interviewing skills. Based on my } \\
\text { previous experience of conducting interviews, I knew I had the } \\
\text { necessary skills in terms of capacity to build rapport and trust } \\
\text { with interviewees as well as the ability to probe and prompt for } \\
\text { detail. } \\
\text { In addition: } \\
\text { - The case study was conducted on a teaching hospital where }\end{array}$ \\
\hline
\end{tabular}




\begin{tabular}{|c|c|}
\hline & $\begin{array}{l}\text { staff are familiar with research and value it. } \\
\text { - The selected hospital showed support of my research and thus } \\
\text { it was easy to find relevant interviewees. } \\
\text { - Both the broader topic of the research (quality and patient } \\
\text { safety improvement) and the more focused theme of falls } \\
\text { prevention were seen by staff as very relevant themes. } \\
\text { - The topics of research were not sensitive nor involved } \\
\text { questions that staff could feel uncomfortable in talking about. } \\
\text { - Before each interview I asked the interviewee if I could audio } \\
\text { record the interview. Audio recording interviews greatly helps } \\
\text { the research process, as it: a) enables the interviewer to be able } \\
\text { to actively listen during the interview and b) ensures that all } \\
\text { the interview content is recorded. However, in case } \\
\text { interviewees felt more comfortable to not be recorded, I took } \\
\text { notes during the interview and this also helped the interview. } \\
\text { - In order to ensure confidentiality and anonymity of interview } \\
\text { data, I transcribed and analyzed all the interviews by myself. } \\
\text { The fact that interviewees were informed about this, also made } \\
\text { them feel that they were sharing their views solely with me } \\
\text { (the person that was in front of them) and not with a stranger } \\
\text { such as a transcriber or someone else analyzing the data. }\end{array}$ \\
\hline $\begin{array}{l}\text { Data loss and } \\
\text { transcription of } \\
\text { interviews }\end{array}$ & $\begin{array}{l}\text { - In all research projects there is always potential for losing data. } \\
\text { I bought a high quality digital voice recorder to ensure that the } \\
\text { quality of recording was good. Before any interview, I ensured } \\
\text { that it was working and that I had spare batteries. Another } \\
\text { strategy frequently used is to record on two devices at the } \\
\text { same time. } \\
\text { - As soon as I arrived home after interviews, I downloaded the } \\
\text { files to the computer and would transcribe them as soon as } \\
\text { possible. Transcribing interviews as soon as possible after the } \\
\text { interview not only made transcribing easier as the content of } \\
\text { the interview was still in my memory but also helped me to } \\
\text { familiarize myself with the data and in case I had any doubt } \\
\text { about any detail from listening to the interviews, I was able to } \\
\text { ask future interviewees for clarification about specific issues. } \\
\text { - The fact that I verbatim transcribed the interviews by myself } \\
\text { also ensured that the quality of the interview transcripts } \\
\text { matched my expectations and were in the format I wanted. } \\
\text { - Having verbatim transcripts of interviews allowed to base the } \\
\text { data analysis on the words that interviewees have said. } \\
\text { - During the visits to the hospital I would always take paper and } \\
\text { pens with me and would jot down any ideas or doubts that } \\
\text { would come to my mind. }\end{array}$ \\
\hline
\end{tabular}

\section{Practical Lessons Learned}

The critical role of the quality of interviews 
After collecting data and verbally summarizing it to a faculty member, I remember them saying something like: "congratulations! You finished your $\mathrm{PhD}$; now you just need to write the thesis". At the time, I was surprised with the comment (as I had not yet written most of the thesis), but looking back, I can clearly see what they meant. Although data is key for all empirical PhD thesis, when doing a qualitative case study using interviews, the quality of the thesis is greatly determined by the richness and level of detail of the interviews. Thus, although I still had to analyze the data and write almost all my $\mathrm{PhD}$ thesis, the detailed and vivid accounts of the events that my interviewees told me, would allow me to easily write-up the empirical part of the thesis in line with the requirements of a $\mathrm{PhD}$.

Indeed, the quality of the research described in this SAGE research methods case has been recognised in a series of ways. First and foremost, in addition to successfully completing my $\mathrm{PhD}$, my PhD Thesis was a Highly Commended winner of the 2014 Emerald/EFMD Outstanding Doctoral Research Awards - category of Healthcare Management. Second, data has been used in articles published in internationally recognised peer-reviewed journals such as Social Science \& Medicine (Melo, 2018), Journal of Health Organization and Management (Melo, 2016) and Human Resource Development Quarterly (Melo \& Beck, 2015) as well as in papers presented at leading international conferences and workshops. A number of other papers are still being written using the data of the case study.

\section{The choice of the case study as a determinant of the success}

I am very grateful to the case study hospital and all the interviewees who dedicated their precious time to tell me about the quality and patient safety initiatives implemented by the hospital, in general and more specifically about patient falls prevention. Doing the case study in a large teaching public hospital considered as a one of the pioneer hospitals in Portugal on quality and patient safety improvement initiatives was a key determinant of success. In practice, conducting the case study at this hospital meant that I not only had the opportunity of interviewing some of the national clinical experts on the topic; but that due to the size of the hospital, my interviewees would have encountered many and varied rich experiences. In addition of being a pioneer hospital, the fact that the hospital is a teaching hospital meant that staff were familiar with research and valued it. Together, the research culture of the hospital, the willingness of staff to help and the high knowledge and experience on quality and patient safety improvement initiatives made the hospital a perfect case study setting. 
As mentioned above, it was through informal conversations with a number of Portuguese healthcare experts that I became aware of this hospital as a potential case study. My previous experience of working at a Portuguese hospital also helped me in knowing more about the structure and context of the Portuguese National Health Service as well as key healthcare terms.

Additionally, the fact that I was from the same region of where the case study hospital is located, I am a Portuguese native speaker like all my interviewees, and the fact that I lived in Portugal most of my life; all made data collection and data analysis much more straightforward than if I had chosen a case study at a setting with which I was not familiar with. I was also able to establish rapport with my interviewees in a much easier way. Additionally, the fact that I could dedicate a few months to data collection and could give my interviewees the flexibility of choosing the day and time that would suit them best for the interview also greatly helped in data collection. Regarding to this, I owe my deep and sincere gratitude to my sponsor, Fundação para a Ciência e a Tecnologia (Foundation for Science and Technology, Portugal) for the generous grant (SFRH / BD / 31350 / 2006) without which I would not have been able to undertake this research. All these facts also greatly impacted on the quality of data collected.

\section{Conclusions}

In any research, the choice of the research methods and design of the research are crucial for the process and outcomes of such research, including the extent which the data is able to answer the research questions as well as the quality of the data collected. The case study design described in this research methods case allowed to understand and analyze the dynamics involved in the creation and development of falls prevention initiatives at the case study hospital and to explore the factors that contributed for the success or otherwise of these initiatives, which were the key aims of my $\mathrm{PhD}$ research.

\section{Exercises and Discussion Questions}


1 - Based on your knowledge about the healthcare system with which you are most familiar with, do you think that the research process of conducting a case study in one of those hospitals would be the same? Why?

2 - When conducting a case study, what is the role of the gatekeeper?

3 - In what ways can the interviewer impact on the quality of data collected through interviews?

4 - When doing a case study, in what ways do data collection and data analysis influence each other?

5 - This SAGE case reports a case study conducted within the context of a PhD thesis. In what ways would the experiences described differ/not differ from research conducted in the context of a master dissertation or research conducted inside an organisation?

\section{References}

Black, T. R. (2002). Understanding social science research. London: Sage Publications.

Braun, V. \& Clarke, V., (2006). Using thematic analysis in psychology. Qualitative Research in Psychology. 3 (2), 77-101.

Currie, G., Humpreys, M., Waring, J., \& Rowley, E. (2009). Narratives of professional regulation and patient safety: The case of medical devices in anaesthetics. Health, Risk \& Society, 11(2), 117-135.

Denzin, N. K. (2008). The art and politics of interpretation. In N. K. Denzin, \& Y. S. Lincoln (Eds.), Collecting and interpreting qualitative materials (pp. 313-344). Los Angeles; London: Sage Publications.

Denzin, N. K. \& Lincoln, Y. S. (Eds.) (2008) Collecting and interpreting qualitative materials, 3rd ed., Los Angeles; London: Sage Publications.

Earthy, S. \& Cronin, A., (2008). Narrative analysis. In N. Gilbert (ed), Researching Social Life, 3rd ed. (420-439). London: Sage Publications.

Flick, U. (2007). Managing quality in qualitative research. Los Angeles; London: Sage Publications.

Huberman, A. M. \& Miles, M. B. (2008). Data management and analysis methods. In N. K. Denzin \& Y. S. Lincoln (Eds.) Collecting and interpreting qualitative materials (pp. 179-210). Los Angeles; London: Sage Publications. 
Joyce, P., Boaden, R. \& Esmail, A. (2005). Managing risk: A taxonomy of error in health policy. Health Care Analysis, 13(4), 337-346.

Lave, J. \& Wenger, E. (1991). Situated learning: legitimate peripheral participation. Cambridge [England]; New York: Cambridge University Press.

Legido-Quigley, H., McKee, M., Nolte, E. \& Glinos, I. A. (2008). Assuring the quality of heath care in the European Union - A case for action. European Observatory on Health Systems and Policies. Observatory Studies Series.

Lieblich, A., Tuval-Mashiach, R. \& Zilber, T. (1998). Narrative research: reading, analysis and interpretation, Applied Social Research Methods Series, Vol. 47, Thousand Oaks, Calif.; London: Sage Publications.

Malcolm, J., Hodkinson, P. \& Colley, H. (2003). The interrelationships between informal and formal learning. Journal of Workplace Learning, 15(7/8), 313-318.

McDonald, R., Waring, J. \& Harrison, S. (2006). Rules, safety and the narrativisation of identity: a hospital operating theatre case study. Sociology of health \& illness, 28(2), 178-202.

Melo, S. (2018). The role of place on healthcare quality improvement: A qualitative case study of a teaching hospital. Social Science \& Medicine. 202, 136-142.

Melo, S. (2016). The impact of accreditation on healthcare quality improvement: A qualitative case study. Journal of Health Organization and Management. 30, 1242-1258.

Melo, S. (2012). Bottom-up patient safety initiatives: A case study of falls prevention initiatives at a Portuguese hospital, unpublished PhD thesis, The University of York, UK.

Melo, S. \& Beck, M. (2015). Intra and inter-organisational learning networks and the implementation of quality improvement initiatives - the case of a Portuguese teaching hospital. Human Resource Development Quarterly, 26(2), pp. 155-183.

Rossman, G. B. \& Rallis, S. F. (2003). Learning in the field: an introduction to qualitative research. Thousand Oaks, Calif.; London: Sage Publications.

Scapens, R. W. (2004). Doing case study research. In C. Humphrey \& B. Lee (Eds.) The real life guide to accounting research: a behind-the-scenes view of using qualitative research methods (pp. 257-279). Amsterdam: Elsevier.

Spencer, L., Ritchie, J., Ormston, R., O’ Connor, W. \& Barnard, M. (2014), Analysis: principles and processes. In J. Ritchie, J. Lewis, C. M. Nicholls, \& R. Ormston (Eds), Qualitative Research Practice: A Guide for Social Science Students and Researchers, 2nd ed., (pp. 269-293). Sage, London.

Slotte, V., Tynjälä, P. \& Hytönen, T. (2004). How do HRD practitioners describe learning at work? Human Resource Development International, 7(4), 481-499.

Tynjälä, P. \& Häkkinen, P. (2005). E-learning at work: theoretical underpinnings and pedagogical challenges. Journal of Workplace Learning, 17(5/6), 318 - 336.

Waring, J., Harrison, S. \& McDonald, R. (2007). A culture of safety or coping? Ritualistic behaviours in the operating theatre. Journal of Health Services Research \& Policy, 12(Supplement 2), 3-9.

Yin, R. K. (2009). Case study research: design and methods, 4th ed. Thousand Oaks, Calif.; London: Sage Publications. 